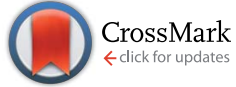

Cite this: Med. Chem. Commun., 2014, 5, 1619

Received 13th June 2014

Accepted 7th August 2014

DOI: $10.1039 / c 4 m d 00255 e$

www.rsc.org/medchemcomm

\section{Synthesis of $\alpha$-brominated phosphonates and their application as phosphate bioisosteres}

\author{
A. Michael Downey† and Christopher W. Cairo*
}

Substrate phosphorylation is a key modulator of signal transduction. Abnormal phosphorylation in vivo is implicated in many diseases including cancer, diabetes, and Alzheimer's disease. Inhibitors of phosphaterecognizing proteins have potential as medicinal agents as well as tools to study phosphorylation pathways. A well-known and common inhibition strategy is to synthetically replace the labile phosphate moiety with a non-hydrolyzable phosphonate. Fully saturated, $\alpha$-fluoro and $\alpha, \alpha$-difluorophosphonates are often effective phosphate bioisosteres and have been well studied. More recently $\alpha$-brominated phosphonates have begun to emerge as inhibitors of phosphate recognizing enzymes, some of which operate by irreversible mechanisms. Herein we discuss the synthetic approaches to aliphatic and benzylic $\alpha$-bromophosphonates and their biological activities.

\section{Introduction: phosphonates and $\alpha$ - halophosphonates as phosphate bioisosteres}

Substrate phosphorylation is a pivotal modulator of cellular function through its regulation of signal transduction pathways. It is estimated that one-third of all cellular proteins are modified through phosphorylation, making this the second most prevalent post-translational modification after glycosylation. Phosphorylation of target molecules is carried out by kinases, acting in opposition to phosphatases, which dephosphorylate these same targets. ${ }^{1}$ A large number of kinases and phosphatases are found in humans which generate or modify phospho-serine, threonine, tyrosine, or histidine residues. ${ }^{1,2}$ Additionally, phosphorylation pathways on lipid- and carbohydrate-based substrates play fundamental biochemical roles in metabolic processing and protein-carbohydrate or lipid recognition. ${ }^{3,4}$

Due to the ubiquitous nature of substrate phosphorylation in cell signaling networks, these pathways are important to physiological processes including cellular differentiation, migration, metabolism, and apoptosis. ${ }^{2,5,6}$ Aberrant phosphorylation pathways can have devastating physiological consequences and may play a role in pathologies including cancer, ${ }^{6}$ diabetes, ${ }^{7}$ and Alzheimer's disease. ${ }^{8}$ As a result of these wide ranging effects, general strategies for the design of improved inhibitors and

Alberta Glycomics Centre, Department of Chemistry, University of Alberta, Edmonton, Alberta, T6G 2G2, Canada. E-mail: ccairo@ualberta.ca; Fax: +1-780-492-8231; Tel: +1-780-492-0377

$\dagger$ Present address: Institute of Organic Chemistry and Biochemistry, Academy of Sciences of the Czech Republic, Gilead Sciences \& IOCB Research Center, Flemingovo nám. 2, 16610 Prague 6 (Czech Republic). probes of this class of enzymes, or the receptors that recognize them, is of continued interest to medicinal chemists. Novel functional groups that can be exploited for inhibitor design may be valuable components of research tools or therapeutic strategies.

It has been known for many years that a general strategy for producing competitive inhibitors of phosphate recognizing proteins is to create substrate mimics that replace the hydrolyzable $\mathrm{C}-\mathrm{O}-\mathrm{P}$ bond of a phosphate with a non-hydrolyzable $\mathrm{C}-\mathrm{C}-\mathrm{P}$ bond to yield a phosphonate moiety. Phosphonates are not only resistant to enzymatic cleavage, hydrolysis of the functional group is also dramatically decreased allowing for synthetic manipulation of the molecule after installation of the phosphonate. ${ }^{9}$ However, there are obvious shortcomings to this strategy. Firstly, replacement of an electronegative oxygen atom with a non-polar methylene group may reduce affinity for the phosphate-recognizing-protein active site. Solubility of the compounds in water may also be decreased. The phosphonate group may also exhibit changes in charge state, for example if the $\mathrm{p} K_{\mathrm{a}}$ of the phosphonic acid is increased above physiological $\mathrm{pH} ;{ }^{10}$ this can make salt bridge or hydrogen bond contacts less favorable in an enzyme active site., ${ }^{9,11}$

An early approach to address this issue was the installation of fluorine atoms on the phosphonate $\alpha$-carbon, thus making the phosphonate a more effective electronic isostere of the phosphate group. ${ }^{12,13} \alpha$-Fluorophosphonates also reduce the $\mathrm{p} K_{\mathrm{a}}$ of the phosphonic acid protons below physiological $\mathrm{pH}$ ( $\left.\mathrm{p} K_{\mathrm{a} 2} \sim 5.6\right)$, restoring the group to the same charge state as a native phosphate $\left(\mathrm{p} K_{\mathrm{a} 2} \sim 6.4\right)$ at physiological $\mathrm{pH}^{11,12}$

Medicinal chemists have more recently exchanged fluorine for bromine to determine the activity of $\alpha$-bromophosphonates as inhibitors. Typical $\mathrm{C}-\mathrm{X}$ bond lengths within $\alpha$-halophosphonate compounds are $1.41 \AA(\mathrm{C}-\mathrm{F}),{ }^{14} 1.79 \AA(\mathrm{C}-\mathrm{Cl}),{ }^{15}$ 
and $1.93 \AA$ (C-Br). ${ }^{16}$ Thus, $\alpha$-bromophosphonates may have different steric requirements than their fluoro-derived counterparts. Additionally, while the bromine atom does not offer the same electronegativity as fluorine, it may act as a good leaving group offering the potential to create covalent labels of enzyme active sites that contain potent nucleophiles. ${ }^{17,18}$ This unique combination of features makes $\alpha$-bromophosphonates a useful tool for the medicinal chemist. Herein we will discuss the synthesis and examples of applications which have exploited $\alpha$ bromophosphonate derivatives in biological studies.

\section{Design, synthesis and evaluation of $\alpha$-bromophosphonates as bioactive compounds}

$\alpha$-Bromophosphonates were first described in the literature over 90 years ago. The earliest example of an $\alpha$-bromophosphonate was isolated as an $\alpha, \beta$-dibromo phosphonic acid intermediate (1, Fig. 1) which was decomposed in the presence of base to provide a $\beta$-bromo- $\alpha, \beta$-unsaturated phosphonic acid. ${ }^{19}$ However, as the use of phosphonates expanded in medicinal chemistry, additional reports of the synthesis of $\alpha$-bromophosphonates as synthetic targets began to emerge. Early examples of $\alpha$-bromophosphonates appeared in a 1953 study of $\mathrm{p} K_{\mathrm{a}}$ values of $\alpha$-substituted phosphonic acids (2). The $\mathrm{p} K_{\mathrm{a}}$ values of compound 2 were found to be 1.14 and 6.52, respectively, ${ }^{20}$ indicating that the $\alpha$-bromophosphonates provide a $\mathrm{p} K_{\mathrm{a}}$ lowering effect over $\mathrm{CH}_{2}$-phosphonates $\left(\mathrm{p} K_{\mathrm{a} 2}=7.7-9.0\right)^{10}$ which more closely matches the acidity of the phosphonate to that of naturally occurring phosphates. This also indicates that the $\alpha$ bromophosphonate group is 10 -fold more basic than the $\alpha$ fluorophosphonate moiety.

The first biological studies of alkyl $\alpha$-bromophosphonates (3) were conducted with $\alpha$-bromophosphonates tested as agricultural chemicals. These compounds were found to be active in killing worms, insects, and bacteria. ${ }^{21}$

\subsection{Benzylic $\alpha$-bromophosphonates}

Synthetic access to benzylic $\alpha$-bromophosphonates (BBP) has been well studied, and these are generally easier to access than their aliphatic counterparts (Scheme 1). This functional group has been exploited as a bioisostere of phosphotyrosine residues in medicinal chemistry. We highlight examples of BBP in the literature, and discuss general strategies for their synthesis below.

2.1.1. Synthetic approaches to BBP. Installation of bromine at the $\alpha$-position of benzylic phosphonates is usually conducted
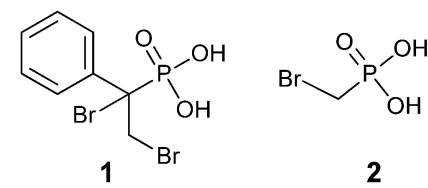

2

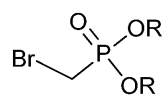

3

Fig. 1 Early examples of $\alpha$-bromophosphonates.

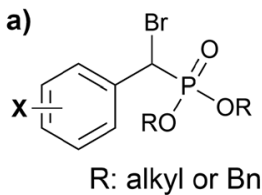

b)<smiles>[R]OP([R])(=O)Cc1ccccc1</smiles>

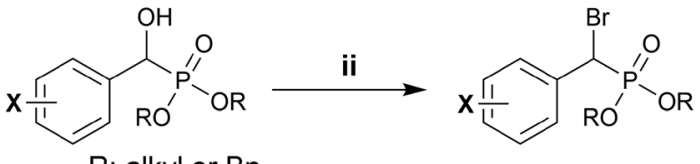

$\mathrm{R}$ : alkyl or $\mathrm{Bn}$

Scheme 1 (a) A generic benzylic $\alpha$-bromophosphonate (BBP). (b) Synthetic strategies for obtaining BBPs.

through one of two general approaches, either (i) direct bromination or (ii) bromination of an $\alpha$-hydroxy benzylphosphonate (Scheme 1b).

A summary of reported conditions used through pathway (i) (Scheme 1b) is given in Table 1. The fully saturated phosphonate precursor is typically converted to the $\alpha$-bromophosphonate through either radical bromination using $\mathrm{N}$ bromosuccinimide (entries 1-4, Table 1) or through deprotonation of the $\alpha$-proton to form a phosphorus-stabilized carbanion that is subsequently quenched with an electrophilic bromine source (entry 5, Table 1). Benzyl diethylphosphonate was subjected to three equivalents of lithium hexamethyldisilazide (LiHMDS) at $-78^{\circ} \mathrm{C}$ and the phosphorus-stabilized anion was quenched with trimethylsilyl chloride (TMSCl) to temporarily install a TMS group at the $\alpha$ position in situ (entry 5). Under these conditions, a second deprotonation occurred simultaneously which was subsequently quenched with an electrophilic bromine source, 1,2-dibromotetrachloroethane (TCDBE). The reaction was then warmed to $0{ }^{\circ} \mathrm{C}$ and lithium ethoxide was added to cleave the TMS group, furnishing the BBP adduct in good yield..$^{29}$ Importantly, for all entries in Table 1, a $1: 1$ mixture of diastereomers at the $\alpha$ position is expected in the absence of any directing groups.

The phosphorous-stabilized carbanion (Scheme 2) has been examined by several groups. The $\mathrm{p} K_{\mathrm{a}}$ of the alkyl phosphonate $\alpha$ proton is relatively high $(\sim 29)^{22}$ and deprotonation requires the use of a strong and non-nucleophilic base to produce the anion. ${ }^{\mathbf{1 2}}$ Cantat et al. confirmed that anionic $\mathrm{C}-\mathrm{P}$ bonds are shorter than $\mathrm{C}-\mathrm{P}$ bonds of the corresponding saturated compounds using crystallography. Computational analysis suggested stabilization of the anion through hyperconjugation resulting from $p(\mathrm{C}) \rightarrow$ $\sigma^{*}(\mathrm{P}-\mathrm{O})$ donation. It was concluded that contact with the metal cation is shared between the $\mathrm{O}=\mathrm{P}-\mathrm{C}$ atoms. ${ }^{23}$

The more common synthetic approach to form BBP is via an $\alpha$-hydroxyphosphonate intermediate (pathway (ii), Scheme $1 \mathrm{~b}$ ). This strategy typically involves milder conditions than the strong basic conditions required for formation of the 
Table 1 Conditions for generation of benzylic $\alpha$-bromophosphonates by bromination of a phosphonate precursor

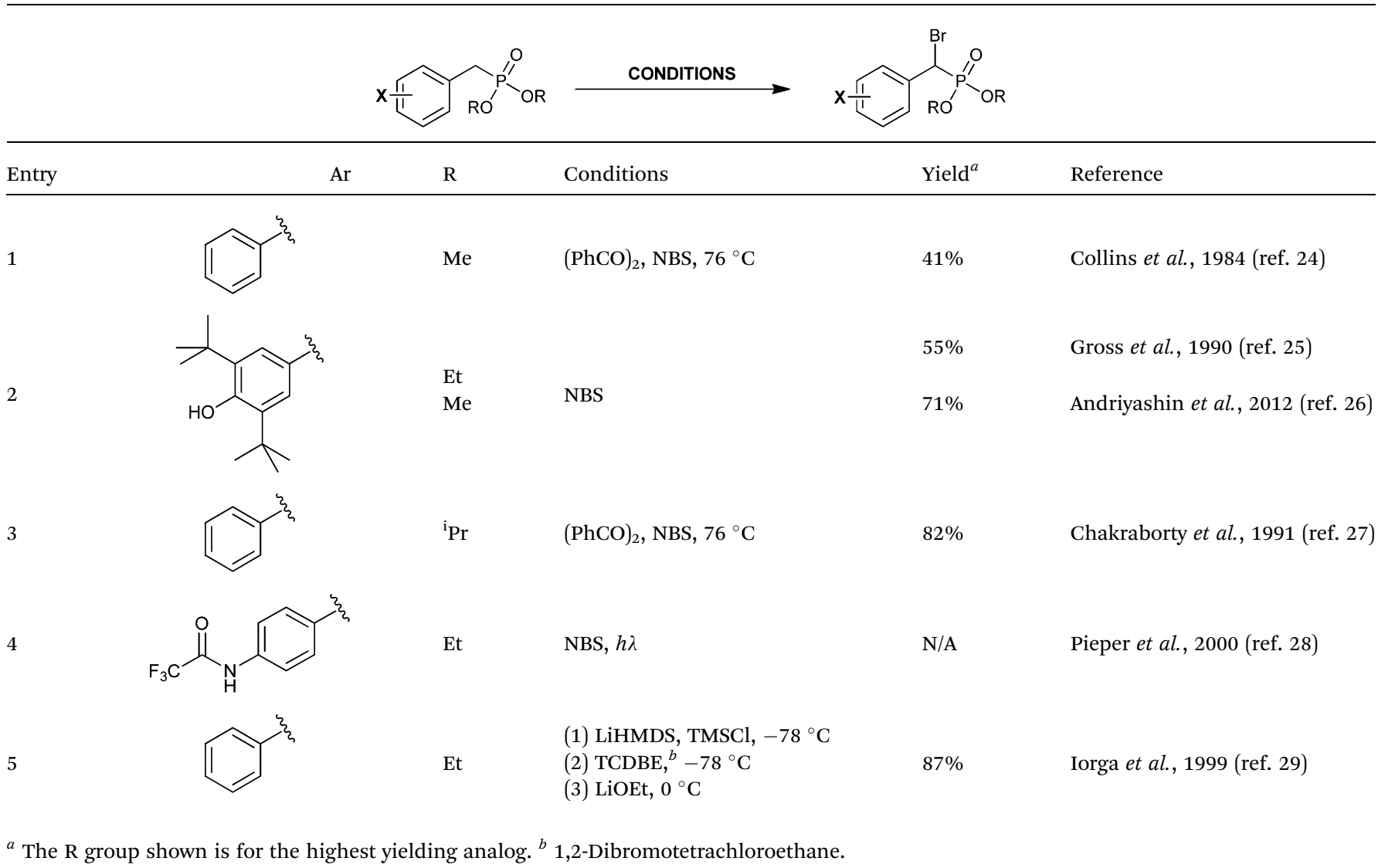

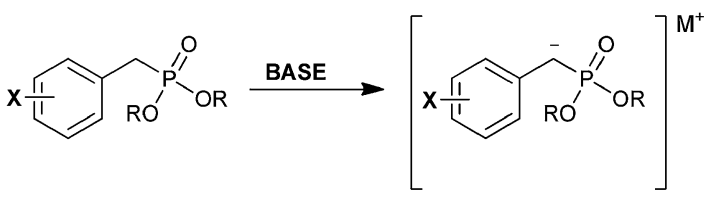

Scheme 2 Deprotonation of a benzylic phosphonate to form a phosphorus-stabilized carbanion.

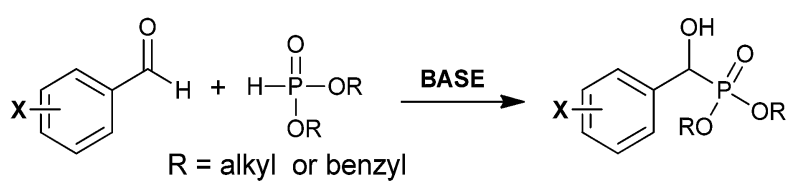

Scheme 3 General form of the Pudovik reaction to generate a benzylic $\alpha$-hydroxyphosphonate.

phosphorus-stabilizied carbanion. Shown in Scheme 3 is a general approach to the synthesis of the parent $\alpha$-hydroxy adduct via Pudovik reaction. ${ }^{30}$ In this transformation, a benzyaldehyde derivative is treated with a deprotonated dialkyl- or diarylphosphite to furnish a diastereomeric mixture of the $\alpha$ hydroxy analog.

After obtaining the $\alpha$-hydroxy precursor, the subsequent bromination reaction can be performed using a variety of conditions. Several methods used to achieve this transformation are summarized in Table 2. Entries 1-8 are examples that achieved benzylic $\alpha$-bromination with an electrophilic bromide source, with yields ranging from $42 \%$ to $100 \%$. Entries 9-13 summarize conditions employed to obtain $\alpha$-brominated phosphonates which were ultimately screened for activity against phosphate recognizing proteins. In all instances, the syntheses required no more than three chemical steps to obtain the target compound. Several analogs tested for activity from the references included in Table 2 are illustrated in Fig. 2. We discuss the biological activity of these species below.

2.1.2. Benzylic $\alpha$-bromophosphonates as irreversible inhibitors. The Widlanski group was the first to examine $\alpha$ bromophosphonates as inhibitors of phosphate recognizing proteins. $^{38}$ BBP analog 4 was screened against a truncated recombinant form of the protein tyrosine phosphatase (PTP), Yop51 (Yop51* 162 ), from Yersinia enterocolitica. The PTP superfamily, which includes Yop51, consists of a key conserved Cys- $\left(\mathrm{X}_{5}\right)$-Arg active site motif, with the cysteine being responsible for catalysis. ${ }^{39}$ Subsequent work has investigated the role of the nucleophilic cysteine residue in displacement of the $\alpha$ bromide to produce a covalent adduct. Two mechanisms for covalent inhibition have been proposed (Scheme 4); in the first, the active site thiolate undergoes a direct $S_{N} 2$ displacement of the $\alpha$-bromide, creating a covalent $\mathrm{C}-\mathrm{S}$ bond that inactivates the enzyme. In the second proposed mechanism the nucleophilic 


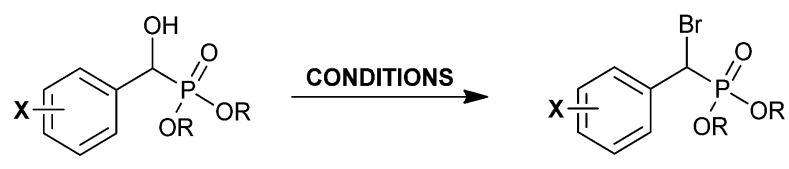

\section{Entry}

$\mathrm{Ar}$

$\mathrm{R}$

Conditions

Yield $^{a}$

Reference

1<smiles>Cc1ccccc1</smiles>

Et

$\mathrm{CBr}_{4}, \mathrm{PPh}_{3}, 80^{\circ} \mathrm{C}$

$42 \%$

Gajda, 1990 (ref. 31)<smiles>Cc1ccccc1</smiles>

Et

$\mathrm{PPh}_{3} / \mathrm{Br}_{2}, \mathrm{pyr}$

$42 \%$

Gajda, 1990 (ref. 31)<smiles>Cc1ccccc1</smiles><smiles>CC(C)(CO)CO</smiles>

$\mathrm{SOBr}_{2}$ or $\mathrm{PBr}_{3}$

$79 \%$

Kumaraswamy et al., 1997 (ref. 32)

4<smiles>CCCOc1ccccc1C</smiles>

Et

$\mathrm{SOBr}_{2}$, pyr

$88 \%$

Gross et al., 1993 (ref. 33)<smiles>COc1ccc(C)cc1</smiles>

Et

CDI, ${ }^{b}$ allyl bromide

$100 \%$

Green et al., 1996 (ref. 34)<smiles>Cc1ccc(Cl)cc1</smiles>

Et

$n$-BuNBr, $\mathrm{PPh}_{3}$, DDQ

$98 \%$

Firouzabadi et al., 2004 (ref. 35)<smiles>CCc1ccc(OC)cc1</smiles>

Et

$\mathrm{APDPP},{ }^{c} \mathrm{Br}_{2}$

$100 \%$

Iranpoor et al., 2006 (ref. 36)<smiles>Cc1ccccc1</smiles>

Et

$\mathrm{SOBr}_{2}$

$80 \%$

Balczewski et al., 2006 (ref. 37)

9<smiles>Cc1ccccc1</smiles>

Et

NBS, pyr

N/A

Taylor et al., 1996 (ref. 38)

10<smiles>Cc1ccc(CNC(=O)OC(C)(C)C)cc1</smiles>

Et

$\mathrm{PPh}_{3} / \mathrm{Br}_{2}$, pyr

$51 \%$

Kumar et al., 2004 (ref. 39)

11<smiles>CCCNC(Cc1ccc(C)cc1)C(C)=O</smiles>

$\mathrm{Me}$

$\mathrm{SOBr}_{2}$, pyr

$88 \%$

Tulsi et al., 2010 (ref. 40)

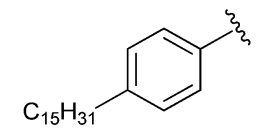

Me

$\mathrm{PBr}_{3}$

N/A

Gupte et al., 2011 (ref. 41)

13

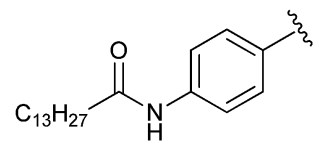

Et

$\mathrm{CBr}_{4}, \mathrm{PPh}_{3}$

$81 \%$

Jiang et al., 2011 (ref. 42)

${ }^{a}$ The R group shown is for the highest yielding analog. ${ }^{b} \mathrm{~N}, \mathrm{~N}$-Carbonyldiimidazole. ${ }^{c}$ 4-Aminophenyldiphenylphosphinite (APDPP). 
<smiles>O=P(O[Na])(O[Na])C(Br)c1ccccc1</smiles>

BBP, 4<smiles>[NH3+][C@H](Cc1ccc(C(Br)P(=O)([O-])[O-])cc1)C(=O)[O-]</smiles>

BrPmP, 6<smiles>O=C(CCCC[C@H]1SC[C@@H]2NC(=O)N[C@@H]21)NCc1ccc(C(Br)P(=O)(O)O)cc1</smiles>

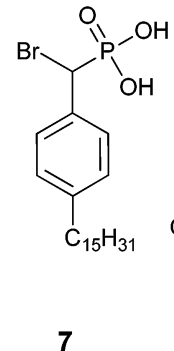

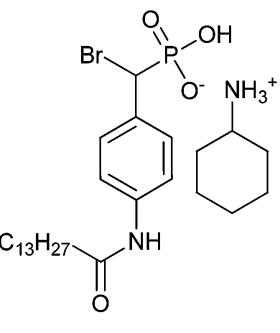

8
Fig. 2 Biologically active BBPs. ${ }^{43}$ a)<smiles>CCCC(Br)(c1ccccc1)P(=O)([O-])O</smiles>

b)

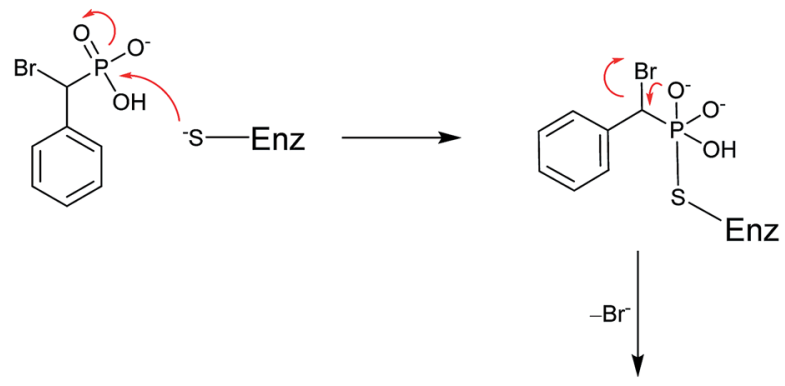<smiles>[R17]#CCSP(=O)(O)C(O)c1ccccc1</smiles>

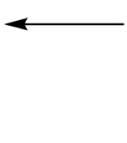

Scheme 4 Proposed mechanisms for covalent inhibition of a PTP by BBP: (a) $\mathrm{S}_{N} 2$ displacement of bromide or (b) intramolecular formation of a three-membered oxaphosphetane-like intermediate.

cysteine attacks phosphorus to provide a pentavalent intermediate. This intermediate then collapses to concomitantly displace the $\alpha$-bromide, resulting in a three-membered oxaphosphetane-like intermediate that may decompose to form the $S$-linked $\alpha$-hydroxyphosphonate. ${ }^{38}$ Mutagenesis experiments implicate a central role for the active site Cys; however, it is not clear which of these pathways is specifically responsible for enzyme inactivation.

Taylor et al. concluded that BBP 4 was an active site-directed covalent inhibitor of Yop51 at low mM concentration. ${ }^{38}$ The absence of activity for probe $\mathbf{4}$ with alkaline phosphatase confirmed its specificity for PTPs. Zhang and co-workers expanded on this finding by constructing BBP analog $5,{ }^{39}$ which was proposed as an activity-based proteomic probe (ABPP) to covalently tag phosphatase enzymes. ${ }^{\mathbf{4 4 5}}$ Analog 5 built on the original BBP design by including an affinity tag, biotin, linked through the para-position of the aromatic ring. This modification enabled streptavidin to be used for detection of bioconjugates formed in the reaction of $\mathbf{5}$ with its targets. Testing of analog 5 as an irreversible inhibitor of YopH, another PTP from Yersinia, showed that its activity was comparable to 4 (Table 3). Compound 5 followed a similar inactivation time course to 4; however, it displayed 5-fold improved specificity for the enzyme. ${ }^{39}$

Importantly, when probe $\mathbf{5}$ was introduced into a mixture PTPs (YopH, PTP1b, HePTP, SHP2, FAP-1, PTP $\alpha$, DEP-1, VHR, Cdc14 and PRL-3) at $1 \mathrm{mM}$ concentration, covalent adducts were formed with all enzymes. Specificity of the reagent toward PTPs was confirmed by comparison to other phosphatase enzymes (alkaline, potato, prostatic acid, DSP and $\lambda$ phosphatases) in vitro as well and among the milieu of cellular proteins found in the cell lysate of E. coli. ${ }^{39}$ These studies were the first to demonstrate that $\alpha$-bromobenzylphosphonates could be used successfully for selective, irreversible inhibition of PTPs as an enzyme class. More recently $\alpha$-BBP analog $\mathbf{5}$ was used by Boivin et al. to identify PTPs and monitor platelet-derived growth factor (PDGF) receptor signaling in an angiomyolipoma cancer cell model. ${ }^{46}$ It is worth noting that these studies also raise the concern that, while extremely active, the $\alpha$-BBP functional group alone does not provide specificity among different PTPs. ${ }^{39}$

Fluorescent tags (9 and 10, Fig. 3) have been incorporated into $\alpha$-BBP derivatives to detect PTPs in breast, lung, liver, ovarian and cervical cancer cell lines. The cell lines could be specifically labeled using these fluorescent probes at a concentration of $1 \mathrm{mM}$. These rhodamine-based regioisomers of $\alpha$-BBP were isolated as a mixture and were not separated (Fig. 3). These analogs offered a slight improvement in $K_{\mathrm{I}}$ over analog 5 (Table 3), but provided 1000-fold more sensitivity for detection of labeled enzyme. ${ }^{47}$

More recently Tulsi et al. developed an improved strategy for the design of BBP-based inhibitors to address the problem of selectivity among PTP enzymes. They approached this issue by developing a method to incorporate $\alpha$-BBP-based analogs into peptides, offering the possibility of increased specificity for

Table 3 Equilibrium binding constant $\left(K_{1}\right)$ and inactivation rate constant $\left(k_{\mathrm{i}}\right)$ for irreversible inhibitors 4, 5, and 9 \& 10 against $\mathrm{YopH}$

\begin{tabular}{lcl}
\hline Analog & $K_{\mathrm{I}}(\mu \mathrm{M})$ & $k_{\mathrm{i}}\left(\mathrm{min}^{-1}\right)$ \\
\hline $\mathbf{4}$ & 4100 & 0.11 \\
$\mathbf{5}$ & 740 & 0.17 \\
$\mathbf{9} \& \mathbf{1 0}$ & 690 & 0.52
\end{tabular}



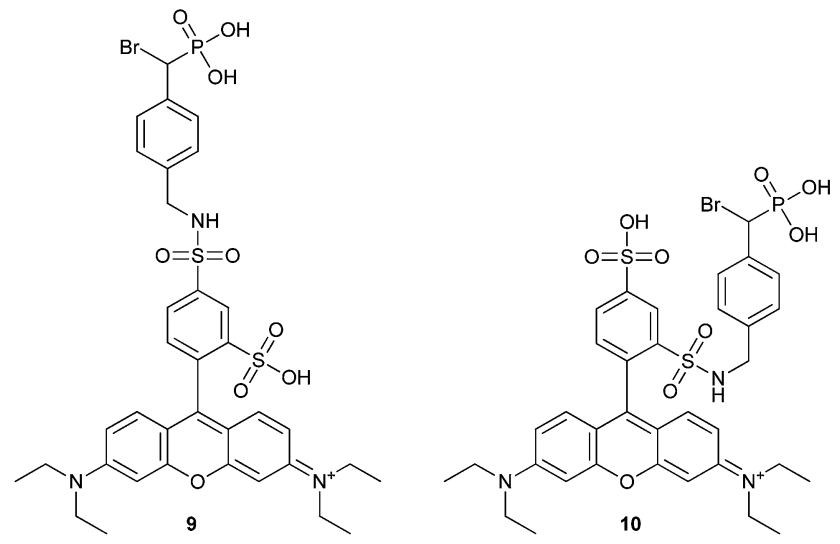

Fig. 3 The structure of fluorescent rhodamine-based $\alpha$-bromophosphonate regioisomers 9 and $10 .^{47}$

individual PTP enzymes and modular synthesis of new inhibitors. The analog was synthesized as a protected phosphotyrosine analog incorporating the $\alpha$-BBP functional group, $\mathrm{L}^{-}$ bromophosphonomethylphenylalanine (BrPmp, 6). BrPmp was the first attempt to incorporate BBP into an amino acid derivative. BrPmp was synthesized from L-tyrosine in 14 steps and $22 \%$ overall yield. It was then incorporated into the tripeptide sequence, Asp-BrPmp-Leu (11, Fig. 4) using solid phase peptide synthesis. This sequence was selected as an example of a short sequence that contained an acidic residue $\mathrm{N}$-terminal to the phosphotyrosine site, and a hydrophobic residue at the Cterminal side-both of which are features commonly found in phosphopeptide substrates of the human PTP enzyme, CD45. While BBP 4 was only a weak inhibitor, BrPmp inhibited CD45 both as an individual amino acid and as part of tripeptide analog $11 .^{40}$

Tulsi et al. confirmed that $\mathbf{6}$ was indeed a covalent inhibitor of CD45 using a Kitz-Wilson analysis with a similar rate of inactivation to that of tripeptide 11. Importantly, they found that BrPmp in the context of the tripeptide had 4 -fold increased specificity for the enzyme over BrPmp alone (Table 4). ${ }^{40}$ These results strongly suggest that an appropriate BrPmp peptide sequence could be used to target an individual PTP enzyme with high potency. The increased specificity of BrPmp in a peptide sequence provides support for this strategy as a means to design new inhibitors or probes that target individual PTPs.<smiles>CC(C)C[C@H](NC(=O)C(Cc1ccc(C(Br)P(=O)(O)O)cc1)NC(=O)[C@H](N)CC(=O)O)C(=O)O</smiles>

11

Fig. 4 Synthetic tripeptide incorporating BrPmp shown to have specificity for immune PTP, CD $45 .{ }^{40}$
Table $4 \quad K_{\mathrm{l}}$ and $k_{\mathrm{i}}$ for inhibitors 6 and 11 against CD45

\begin{tabular}{lll}
\hline Analog & $K_{\mathrm{I}}(\mu \mathrm{M})$ & $k_{\mathrm{i}}\left(\mathrm{min}^{-1}\right)$ \\
\hline $\mathbf{6}$ & $40 \pm 8$ & $0.041 \pm 0.001$ \\
$\mathbf{1 1}$ & $16 \pm 4$ & $0.048 \pm 0.003$
\end{tabular}

2.1.3. Benzylic $\alpha$-bromophosphonates as inhibitors of invasive and metastatic pathways. Benzylic $\alpha$-bromophosphonates have been investigated as inhibitors of invasion and metastasis in cancer cell lines. $\alpha$-Bromobenzylphosphocholine derivatives have been synthesized as potential inhibitors of autotaxin (ATX), which catalyzes the hydrolysis of lysophosphatidylcholine to form the bioactive lipid lysophosphatidic acid (LPA, Fig. 5). ${ }^{48}$ ATX expression is upregulated in numerous cancers and has been shown to aid in tumor cell motility, resulting in implications for metastasis and invasion, as well as chemotherapy resistance. ${ }^{\mathbf{4 1 , 4 2 , 4 9}}$ LPA itself has demonstrated mitogenic, motogenic and anti-apoptotic properties that increase survival of carcinomas that use LPA in an autocrine and paracrine fashion. ${ }^{\mathbf{4 1}}$ Therefore, inhibitors of ATX provide an opportunity to reduce both ATX-induced and LPA-induced effects in cancer. ${ }^{50}$

In 2008, ATX inhibitor S32826 (Fig. 5) was identified as the first nanomolar inhibitor of ATX $\left(K_{\mathrm{I}}=9.0 \mathrm{nM}\right)^{42}$ by highthroughput screening; however, it showed no inhibitory activity in vitro or in vivo. ${ }^{41}$ Gupte et al. ${ }^{41}$ postulated that the reason for this lack of activity was due to cleavage of the amide bond by other enzymes. The authors synthesized a library of S32826based analogs, including $\alpha$-bromophosphocholine 7 , which offered the advantage of a non-hydrolyzable aliphatic chain para to the alkyl chain. Compound 7 demonstrated a mixed mode of inhibition for ATX $\left(\mathrm{IC}_{50}=10.1 \mu \mathrm{M}\right)$ with a $K_{\mathrm{I}}$ value of $6.10 \mu \mathrm{M}$ and $K_{\mathrm{I}}^{\prime}$ value of $2.97 \mu \mathrm{M} .{ }^{51}$ Compound 7 was a much better inhibitor of ATX than the $\alpha$-chloro derivative and was similar to the $\alpha$-fluoro analog of the same scaffold. Interestingly, the analogous fully saturated phosphonate 12 (Fig. 5) was a much more potent inhibitor of ATX $\left(\mathrm{IC}_{50}=0.17 \mu \mathrm{m}, K_{\mathrm{I}}=0.27\right.$ $\mu \mathrm{m}$, and $\left.K_{\mathrm{I}}^{\prime}=0.28 \mu \mathrm{m}\right)$ and was therefore tested more rigorously. Analog 12 showed significantly $(p<0.05)$ decreased LPAdependent MM1 heptocarcinoma cell invasion of human umbilical vein endothelial cells (HUVEC), at a concentration of $3 \mu \mathrm{M}$. The authors observed that compound 12 exhibited antimetastatic properties in B16-F10 melanoma cells, with a

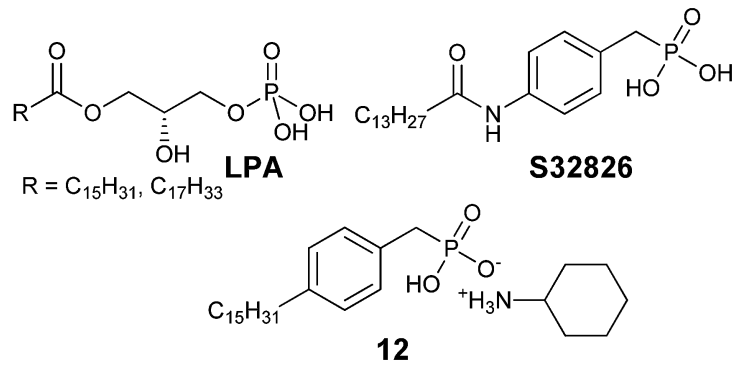

Fig. 5 LPA and related synthetic analogs. 
reduction in metastasis $(p<0.05)$ at concentrations of $0.5 \mathrm{mg}$ $\mathrm{kg}^{-1}$ day $^{-1}$ for 21 days. $^{41}$

The Prestwich group tested an $\alpha$-BBP derivative of S32826, compound 8. They argued that the lack of in vitro and in vivo activity was due to the low solubility of S32826. As a result, they opted to preserve the amide functionality and reduce the aliphatic chain length found in S32826. One resulting compound, $\alpha$-bromophosphonate 8 , was found to inhibit ATX with nearly a 1000 -fold improvement in potency $\left(K_{\mathrm{I}}=8.1 \mathrm{nM}\right)$ over compound 7 . This activity was also a 20 -fold improvement over compound $\mathbf{1 2}$ and offered slight improvement over S32826. ${ }^{42}$ These data suggest that the amide bond is crucial to potency toward ATX. We speculate that the limited activity of $\mathbf{1 2}$ and S32826 in vitro or in vivo could also be due to the reduced stability of these compounds, as hypothesized by Gupte $e$ t al. ${ }^{\mathbf{4 1}}$

Although there are an appreciable number of early synthetic examples that incorporate the $\alpha$-BBP functionality, interest in their application to inhibit phosphate recognizing proteins was not explored until the mid-nineties. We believe that the examples discussed above highlight the untapped potential of benzylic $\alpha$-bromophosphonates as irreversible inhibitors and probes of enzyme activity.

\subsection{Aliphatic $\alpha$-bromophosphonates}

There are far fewer synthetic examples of aliphatic $\alpha$-bromophosphonates relative to $\alpha$-benzylbromophosphonates; however, several biologically active analogs have been identified and tested. We summarize the synthesis and biological properties of these below.

2.2.1. Synthetic approaches. Synthesis of aliphatic $\alpha$-bromophosphonates and $\alpha$-halophosphonates is generally more difficult than that of $\alpha$-BBPs. Interestingly, only a few synthetic reports have utilized an $\alpha$-hydroxy precursor, which is the most commonly used parent compound for creating benzylic $\alpha$ bromophosphonates.

An early example of an aliphatic $\alpha$-bromophosphonate synthesis was reported by Teulade and Savignac, where they synthesized a series of five aliphatic $\alpha$-bromophosphonates. The synthesis of propyl $\alpha$-bromophosphonate derivative $\mathbf{1 6}$ is shown in Scheme 5. Compound $\mathbf{1 4}$ was generated via silylation of a phosphorus-stabilized carbanion intermediate and subsequent

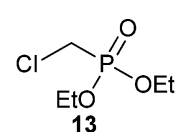

1) 2 eq. $n$-BuLi, TMSCI 2) Etl, $-90^{\circ} \mathrm{C}, 88 \%$

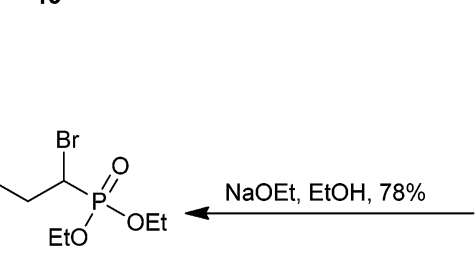

16
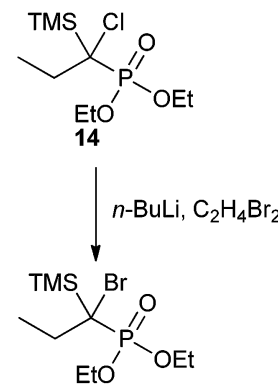

15
Scheme 5 The synthesis of an aliphatic $\alpha$-bromophosphonate derivative..$^{52}$ alkylation in one pot using two equivalents of $n$-BuLi, TMSCl, and ethyl iodide. Subsequent treatment of analog 14 with $n$ BuLi in the presence of 1,2-dibromoethane resulted in halogenlithium exchange of the chlorine atom (15). In a second one-pot procedure, the $\alpha$-bromo- $\alpha$-silylphosphonate was converted to the final $\alpha$-bromo product by removal of the TMS group with sodium ethoxide in ethanol to furnish 16 in 78\% yield as a diastereomeric mixture. ${ }^{52}$

Savignac and co-workers later reported an improvement to this aliphatic bromination strategy that avoided the need for $\alpha$ chlorophosphonate 13 (Scheme 6).$^{53}$ Instead, they utilized the Michaelis-Arbuzov reaction by treatment of triethylphosphite with an alkyl halide under reflux to obtain the starting alkyl phosphonate. ${ }^{54}$ A number of alkyl phosphonates were synthesized using this method; however, Scheme 6 only depicts the synthesis of a single representative ethyl adduct, 20. Treatment of compound 17 with 2 equivalents of lithium diisopropyl amide (LDA) to generate a phosphorus-stabilized carbanion, followed by dropwise addition of TMSCl, produced intermediate 18 which was confirmed through ${ }^{31} \mathrm{P}$ NMR studies. Lithium-bromine exchange was performed using tetrachlorodibromoethane. Finally, intermediate 19 was desilylated using lithium ethoxide in ethanol to furnish $\alpha$-bromophosphonate $\mathbf{2 0}$ as a diastereomeric mixture in nearly quantitative yield from $17 .{ }^{53}$ In 2007, the Fu group also synthesized 20 using this procedure, but reported a more modest yield of $70 \% .^{55}$

To the best of our knowledge, the only other use of this methodology has been reported by Wnuk et al. Lithiumbromine exchange was used to convert saturated phosphonate 21 into $\alpha$-bromo analog 22 as a precursor to radical cyclization (Scheme 7). ${ }^{56}$

Although methodology for obtaining aliphatic $\alpha$-bromophosphonates via an $\alpha$-hydroxy intermediate has not been
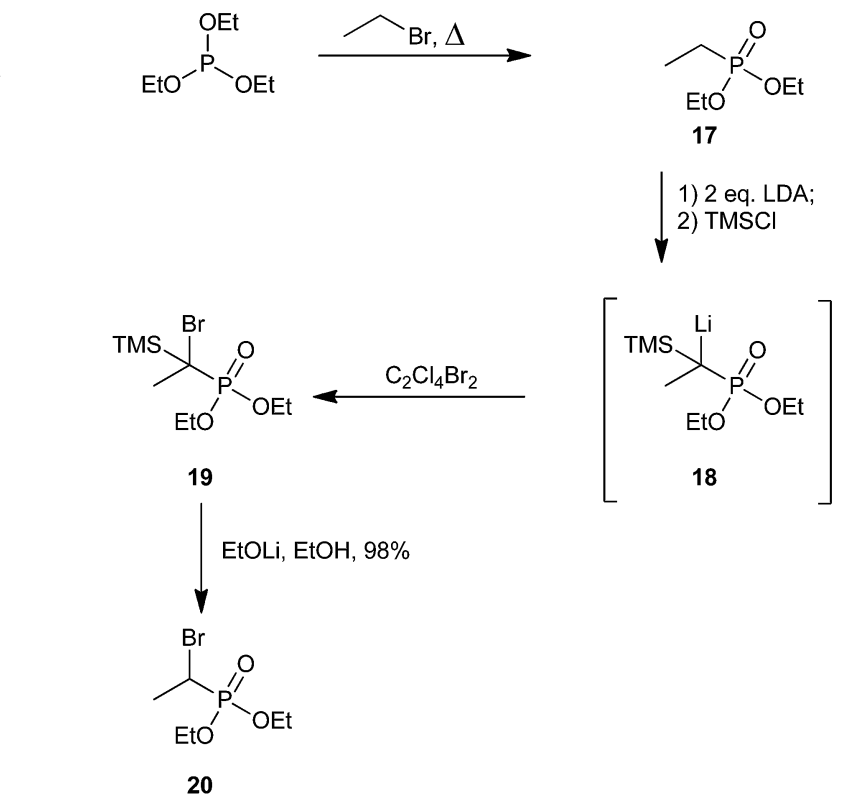

Scheme 6 An improved synthetic strategy to alkyl $\alpha$ bromophosphonates. ${ }^{53}$ 
<smiles>C=CCCCCP(=O)(OCC)OCC</smiles>

21
1) 2 eq LDA

2) $\mathrm{TMSCl}$

3) $\mathrm{C}_{2} \mathrm{Cl}_{4} \mathrm{Br}_{2}$

4) EtOLi, EtOH, $78 \%$

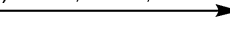

22
Scheme 7 An $\alpha$-bromophosphonate as a precursor for radical cyclization. ${ }^{56}$

explored as thoroughly as for the $\alpha$-BBP moiety, it has been used with moderate to good yields. This conversion generally utilizes far milder conditions and provides the opportunity to obtain enantiopure products, which has not yet been achieved via lithium-bromine exchange.

Fu and co-workers conducted a methodological study on this transformation by bromination of a library of $\alpha$-hydroxyphosphonates using mild conditions. Scheme 8 shows an example using an alkyl phosphonate. $\alpha$-Hydroxypropylphosphonate 23 was brominated to obtain $\mathbf{2 4}$ using either $\mathrm{PPh}_{3} / \mathrm{Br}_{2}$ and pyridine or $\mathrm{PPh}_{3}$, DDQ and $\mathrm{Bu}_{4} \mathrm{NBr}^{.7}$ Mechanistic studies appear to rule out a radical pathway. ${ }^{35}$ Analog 24 was used as an intermediate for subsequent fluorination via a phosphorus-stabilized carbanion using $\mathrm{N}$-fluorobenzenesulfonimide (NFSI). Although the authors discussed the potential importance of these $\alpha$-bromo- $\alpha$-fluorophosphonate analogs as inhibitors of PTPs, they did not report biological testing. ${ }^{57}$

We focus now on examples of aliphatic $\alpha$-bromophosphonates that have been assayed as inhibitors of phosphate recognizing proteins.

2.2.2. Aliphatic $\alpha$-bromophosphonate analogs of LPA. Aliphatic $\alpha$-bromophosphonates have been screened against phosphate recognizing proteins involved in the ATX-LPA pathway as anti-invasive and anti-metastatic agents (vide supra). Prestwich and co-workers used an $\alpha$-hydroxyphosphonate as the bromination precursor, which allowed for separation of the two epimers downstream (Scheme 10). Scheme 9 depicts the synthesis of $\alpha$-bromophosphonates $27 \mathbf{a}$ and $27 \mathbf{b}$. The parent $\alpha$ hydroxy analog, 25, was treated with $\mathrm{CBr}_{4}$ and $\mathrm{PPh}_{3}$ to obtain alkyl $\alpha$-bromo analog 26 in moderate yield. Biologically active phosphonates $27 \mathbf{a}$ and $\mathbf{2 7} \mathbf{b}$ were then obtained through acylation and phosphonate ester hydrolysis. ${ }^{50}$

By treating analog 25 with tert-butyldimethylsilyl chloride (TBDMSCl) under basic conditions, the resulting bulky siloxane product could be separated using flash chromatography. The

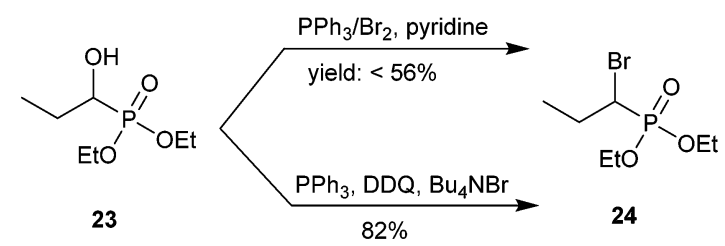

Scheme 8 Electrophilic bromination of aliphatic $\alpha$-bromophosphonates. ${ }^{57}$

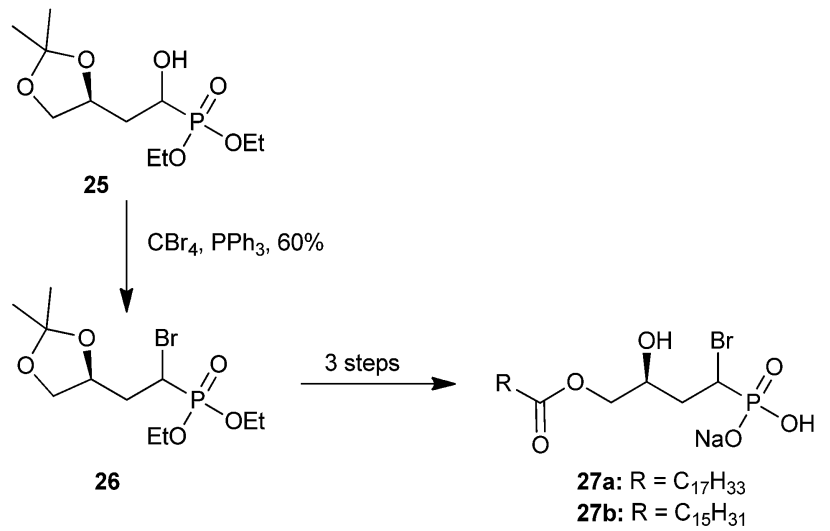

Scheme 9 The synthesis of biologically active $\alpha$-bromo analogs 27 a and $27 \mathrm{~b}$ via $\alpha$-hydroxy intermediate $25 .{ }^{50}$
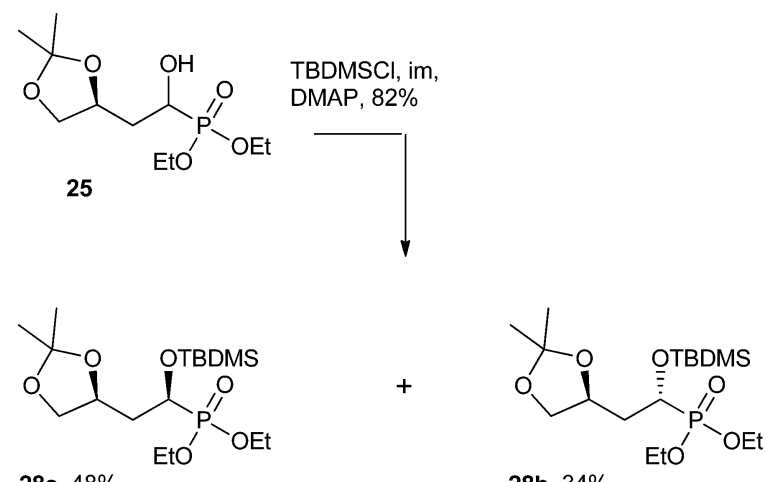

$28 a, 48 \%$

28b, $34 \%$

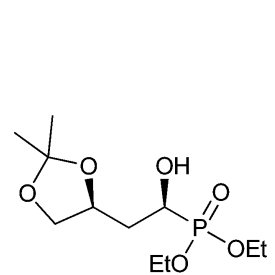

25-syn, $83 \%$

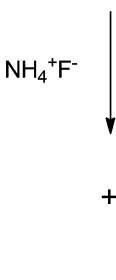

Scheme 10 The separation of $\alpha$-hydroxy derivative 25 into its two diastereomers. ${ }^{50}$

TBDMS group was then cleaved using ammonium fluoride $\left(\mathrm{NH}_{4} \mathrm{~F}\right)$ to furnish the isolated $\alpha$-hydroxy diastereomers (25-syn, 25-anti, Scheme 10). ${ }^{50}$

2.2.3. $\alpha$-Bromophosphonates as inhibitors of cell invasion and metastasis. Aliphatic derivatives $27 \mathbf{a}$ and $27 \mathbf{b}$ were designed to target the G-protein coupled receptors (GPCRs) of LPA, which regulate cancer cell proliferation, invasion, and angiogenesis. Compounds $27 \mathbf{a}$ and $\mathbf{2 7 b}$ were found to inhibit the four GPCRs screened, $\mathrm{LPA}_{1}, \mathrm{LPA}_{2}, \mathrm{LPA}_{3}$ and $\mathrm{LPA}_{4}$ with $K_{\mathrm{I}}$ values ranging from $0.17 \mu \mathrm{M}$ to $2.5 \mu \mathrm{M}$. Interestingly, the analogous $\alpha$-chloro and $\alpha$-hydroxy derivatives of $27 \mathbf{a}$ and $27 \mathbf{b}$ were less active against $\mathrm{LPA}_{1-4} \cdot{ }^{50}$ It is not clear if the mode of action involves covalent modification of the receptors.

In a follow up study, Prestwich and co-workers tested the activity of diastereomeric $\alpha$-bromo derivatives $27 \mathbf{b}$-syn and $27 \mathbf{b}$ anti in LPA-ATX signal transduction (Fig. 6). They termed the 


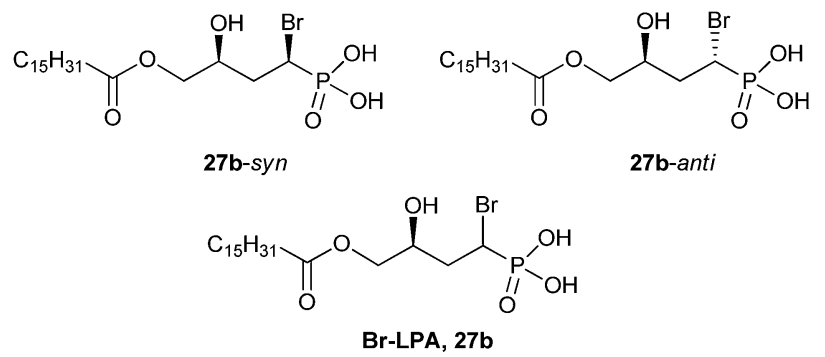

Fig. 6 The structures of two LPA-based $\alpha$-bromophosphonate diastereomers, 27b-syn and 27b-anti. A $1: 1$ mixture of 27b-syn and 27banti was termed $\mathrm{Br}-\mathrm{LPA}(27 \mathrm{~b}){ }^{5}$

collective syn and anti isomers of analog $27 \mathbf{b}$ as Br-LPA. In initial tests of the syn and anti-isomers as separate compounds against $\mathrm{LPA}_{1-4}$ receptors, both were found to be inhibitors of the GPCRs on their own, as had been predicted using molecular modeling. When screened against ATX, the anti-isomer $\left(\mathrm{IC}_{50}=\right.$ $22 \mathrm{nM}$ ) was determined to be a better inhibitor than the synisomer $\left(\mathrm{IC}_{50}=165 \mathrm{nM}\right)$; however, both isomers inhibited ATX in a dose-dependent manner. Furthermore, compounds 27b-syn, 27b-anti, and Br-LPA knocked out $98 \%$ of ATX activity at a concentration of $10 \mu \mathrm{M}$, but were only weakly active against platelet-activating $\mathrm{LPA}_{5} .{ }^{5}$

Further exploration of Br-LPA in breast and lung cancers in vitro and in vivo have suggested these compounds may have therapeutic potential..$^{58}$ Compounds $27 \mathbf{b}$-syn and $27 \mathbf{b}$-anti were tested as inhibitors of LPA-dependent cancer cell migration. Both analogs reduced migration of MDA-MB-231 breast cancer cells at a concentration of $40 \mu \mathrm{M}$, using a scratch wound assay. Both isomers also reduced MDA-MB-231 breast cancer cell invasion by $\sim 50 \%$; interestingly, the potency of the two diastereomers were not significantly different. ${ }^{5}$ Follow-up studies have since found that Br-LPA can reduce tumor size in breast ${ }^{5}$ and lung ${ }^{59}$ tumor models in mice, and the compound had limited toxicity.

2.2.4. Br-LPA as an LPA substrate mimic in neuropathic pain. Recently, the Rosenbaum group determined that LPA acts as a direct substrate for the TRPV1 ion channel. This channel is expressed in primary afferent nociceptors, and is sensitive to stimuli such as high temperature and low $\mathrm{pH}$, which result in hyperalgesia in neuropathic pain. Furthermore, Rosenbaum and co-workers showed that none of the LPA receptors discussed above are implicated in TRPV1 channel activation by LPA. In order to conclude that LPA receptors were not implicated in TRPV1-induced hyperalgesia, the authors compared LPA-induced activation of TRPV- 1 to Br-LPA-induced activation. They observed that both LPA and Br-LPA activated TRPV1 with similar dose-responses (LPA: $K_{\mathrm{D}}=754 \mathrm{nM}$; Br-LPA: $K_{\mathrm{D}}=1.1 \pm$ $0.25 \mu \mathrm{M})$. These data were very encouraging, as Br-LPA is a panselective antagonist of LPA receptors. Therefore, because Br-LPA has a similar dose-response to LPA, this indicates direct TRPV1 channel activation by LPA and that the LPA receptor pathway is not involved in the response. They also demonstrated that Br-LPA injections in wild-type mice mimicked the

effects of LPA at the same dose and little effect was observed in $\operatorname{Trpv} 1^{-/-}$knock-out mice, comparable to LPA. ${ }^{60}$

\section{3. $\alpha$-Bromophosphonates on a carbohydrate scaffold}

Phosphonate-based mimics of carbohydrates are also well known in the literature. ${ }^{9}$ The first example of phosphonate synthesis in carbohydrates appeared over 50 years ago by Griffin and Burger when they synthesized glucose-6-phosphate analog, 29 (Fig. 7). ${ }^{61}$ Since that time, a range of carbohydrate phosphonate analogs have been targeted with general access available at all positions of pyranosides and furanosides (e.g. 30). ${ }^{9,62,63}$ Work to date towards glycosyl $\alpha$-halophosphonate analogs has focused on the introduction of $\alpha$-fluoro and $\alpha, \alpha$ difluorophosphonates at various positions of $O$ - and $C$-glycosides (e.g. 31) ${ }^{12,64}$ Important advances in the synthesis of both $\alpha$ fluorinated and $\alpha, \alpha$-difluorinated glucosyl-6-phosphonates have been described by the Berkowitz group (Scheme 11). By treating $\alpha$-hydroxyphosphonate $\mathbf{3 2}$ with diethylaminosulfur trifluoride (DAST) $\alpha$-fluorophosphonate 33 was obtained in moderate yield, which could be resolved as a diastereomeric mixture by column chromatography. ${ }^{11}$ To obtain the related $\alpha, \alpha$-difluorophosphonate, Berkowitz and co-workers displaced triflate $\mathbf{3 4}$ using a phosphorus-stabilized carbanion, [diethylphosphono(difluoromethyl)]lithium, to provide $\alpha, \alpha$-difluorophosphonate 35 in good yield..$^{11,65-67}$ These examples illustrate the accessibility of $\alpha$-fluorophosphonates; however, until recently there was no corresponding precedent to the $\alpha$ brominated phosphonates on a carbohydrate scaffold.

We recently approached this problem by developing synthetic methods to access glucose-6-phosphate (G6P) derived $\alpha$-bromophosphonates (36, Fig. 8) as inhibitors of glucose-6phosphatase (G6Pase).$^{68}$ Specific inhibitors of G6Pase are of interest to both medicinal and biochemists ${ }^{69}$ as G6Pase activity is upregulated in type II diabetes and no crystal structures of human G6Pase are available.,70 G6Pase is known to contain a nucleophilic histidine and G6Pase analog 37 was hypothesized to be a potent or even irreversible inhibitor of the enzyme. ${ }^{68}$

Initial access to compound $\mathbf{3 7}$ was attempted via reduction of an $\alpha$-bromo- $\alpha, \beta$-unsaturated phosphonate intermediate (38, Scheme 12) using standard hydrogenation conditions. This
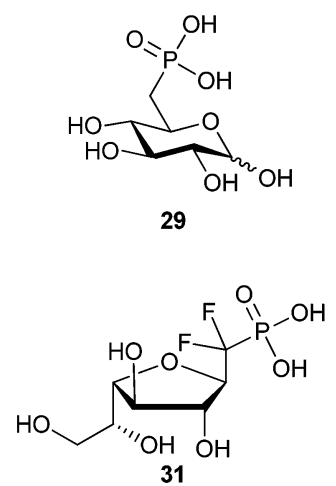

Fig. 7 Examples of known carbohydrate-based phosphonates. 
compound 37 when incubated for 12 hours in rat liver microsomes. This finding suggested that inhibition may be a result of phosphonic acid analog $\mathbf{3 7}$ after cleavage by a native esterase. There was no evidence of irreversible inhibition of G6Pase by any of the $\alpha$-bromophosphonates screened, and future work will be required to confirm the mode of inhibition. ${ }^{68}$

\section{4. $\alpha$-Bromo- $\alpha, \beta$-unsaturated phosphonates}

The $\alpha$-bromo- $\alpha, \beta$-unsaturated phosphonate functional group of compound 40 generated active inhibitors of G6Pase. ${ }^{68}$ This novel functional group has been tested for biological activity in only one other instance. Fosmidomycin (46, Fig. 10) has shown promise in clinical trials for malaria by targeting the mevalonate-independent isoprenoid biosynthesis pathway in this bacterium. ${ }^{71,73,74}$ Fosmidomycin inactivates the essential 1deoxy-D-xylulose 5-phosphate reductoisomerase (DXR) enzyme in this pathway $\left(\mathrm{IC}_{50}=35 \mathrm{nM}\right.$ in recombinant $E$. coli $\left.\mathrm{DXR}\right)$. Devreux et al. synthesized a small library of $\alpha$-arylphosphonates (not shown) using either Stille or Suzuki coupling via fully protected $\alpha$-bromophosphonate 47 . The results of assays with the $\alpha$-functionalized phosphonates against recombinant $E$. coli DXR found that only $\alpha$-bromophosphonate 47 had a submicromolar $\mathrm{IC}_{50}(450 \mathrm{nM}) .^{71}$

\section{5. $\alpha$-Bromophosphonocarboxylates and $\alpha$ - bromobisphosphonates}

Phosphonocarboxylates and bisphosphonates have a host of medicinally important effects ranging from the prevention of bone resorption to cancer chemotherapy as bioisosteres of pyrophosphate. ${ }^{75,76}$ Bisphosphonates are well known to have affinity for bone. ${ }^{76}$ The reactivity of both bisphosphonate and phosphonocarboxylate analogs is dramatically increased over their monophosphonate counterparts. Additionally, both mono- and dibrominated bisphosphonates have been reported. We briefly highlight synthetic access to $\alpha$-bromophosphonocarboxylates and $\alpha$-bromobisphosphonates and offer a discussion of their applications in medicinal chemistry.

Synthetic efforts by McKenna and co-workers have demonstrated di- or mono-bromination of triethyl phosphonoacetate (48), in one or two steps, respectively (Scheme 14). Treatment of 48 with $\mathrm{NaOBr}$ provided triethyl dibromophosphonoacetate (49) in good yield, and the product could be reduced to the monobrominated analog 50 in the presence of 0.96 equiv. of $\mathrm{SnCl}_{2}$ if desired. ${ }^{77}$ Several researchers have utilized this methodology to obtain $\alpha$-bromo and $\alpha, \alpha$-dibromophosphonoacetates on similar scaffolds with moderate to excellent yields. ${ }^{78-86}$ Examples of<smiles>O=CN(O)CCCP(=O)(O)O</smiles><smiles>CC(=O)N(O)CC=C(Br)P(=O)(O[13CH3])O[18OH]</smiles>

Fig. 10 Structures of fosmidomycin (46) and $\alpha$-bromo- $\alpha, \beta$-unsaturated phosphonate 47 that was screened against recombinant $E$. coli DXR. ${ }^{71}$

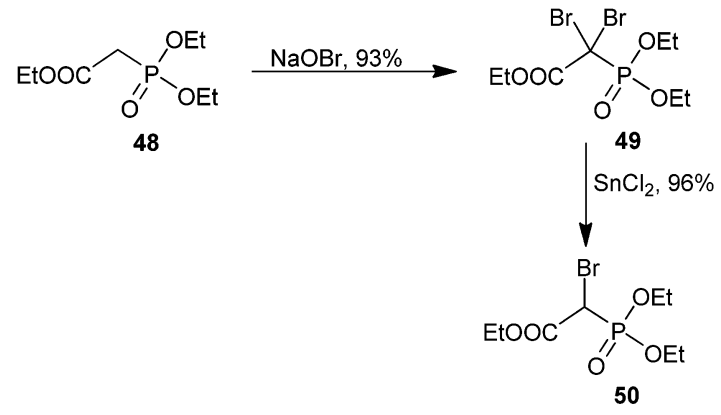

Scheme 14 Access to $\alpha$-bromo and $\alpha, \alpha$-dibromophosphonoacetates.

access to brominated bisphosphonates using similar conditions are available. ${ }^{87-89}$

We note that the $\mathrm{p} K_{\mathrm{a}}$ of the $\alpha$-proton in phosphonocarboxylates and bisphosphonates is significantly lowered, allowing for the formation of either a bisphosphonate-stabilized carbanion or phosphorus-carboxylate-stabilized carbanion to occur under milder conditions than in monophosphonates. Quenching the anion with an electrophilic bromine source subsequently provides the expected $\alpha$-brominated phosphonocarboxylate and bisphosphonate analog. Suitable bases include $n$-BuLi, ${ }^{90} \mathrm{LDA}^{\mathbf{9 1}}$ LiHMDS, ${ }^{92}$ and $\mathrm{NaH}^{68,81,93-95}$

The McKenna group was able to develop $\alpha$-halo derivatives of $\alpha$-hydroxy compounds 53a and 53b (Scheme 15), which are known anti-osteoporotic agents that act through blockage of prenylation. These compounds are also known to bind bone minerals. ${ }^{75,76,96}$ Protected benzylic bisphosphonates and phosphonocarboxylates were brominated via a stabilized carbanion generated by treatment with $\mathrm{NaH}$ and quenched with NBS. This strategy provided analogs 52a and 52b in good yields (Scheme 15) ${ }^{75,96}$ Unfortunately, testing of the biologically active, free acid form of $\alpha$-bromo analogs $52 \mathbf{a}$ and $\mathbf{5 2 b}$ indicated they were generally less active than the previously studied $\alpha-\mathrm{OH}$ analogs 53a and 53b. ${ }^{75,96}$

\subsection{Mono- and dibrominated polyphosphonates}

Both nucleoside and non-nucleoside polyphosphonate analogs have been proposed for use in medicinal applications. We

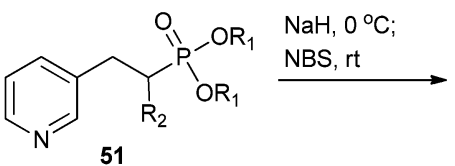

51a: $\mathrm{R}_{1}={ }^{i} \mathrm{Pr}, \mathrm{R}_{2}=\mathrm{P}(\mathrm{O})\left(\mathrm{O}^{i} \mathrm{Pr}\right)_{2}$ 51b: $R_{1}=E t, R_{2}=\mathrm{CO}_{2} \mathrm{Et}$

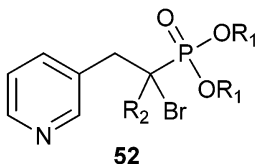

52a: $93 \%$

52b: $88 \%$

Scheme $15 \alpha$-Bromination of benzyl bisphosphonates and phosphonocarboxylates via a bisphosphonate-stabilized (51a to 52a) or phosphorus-carboxylate-stabilized (51b to 52b) carbanion. ${ }^{75,96}$ 
<smiles>[R]OP(=O)(CCNC(=O)OCC1c2ccccc2-c2ccccc21)OP(=O)(O)C(Br)(Br)[PH]([R])([R])[R]</smiles><smiles>CC(C)OC(=O)NCCP(=O)(O)O</smiles>

55

CDI, $16 \%$

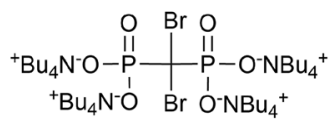

54
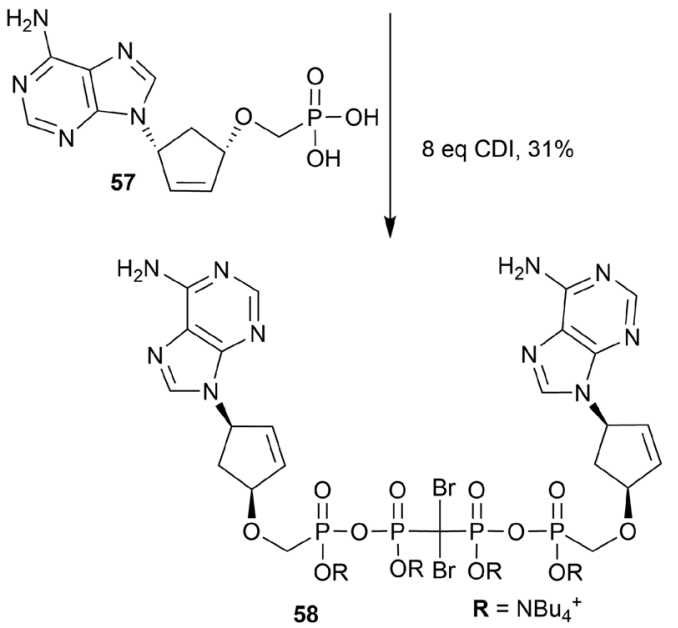

Scheme 16 Synthesis of dibromo-polyphosphonate analogs 56 and $58{ }^{97-99}$

highlight the syntheses that incorporate dibromo-polyphosphonate moieties into this class of molecules (Scheme 16). General access to these seemingly intricate brominated polyphosphonate analogs begins from bisphosphonate (54) and a carbodiimide (CDI)-activated phosphonate $\left(55^{97,98}\right.$ or $\left.57^{99}\right)$. Yields are generally moderate, and both the adenine and guanine analogs of carbocyclic dinucleoside 57 were synthesized (e.g. 58). In all instances the $\mathrm{NBu}_{4}^{+}$phosphonate salts were isolated.

Non-nucleoside triphosphate analogs are inhibitors of terminal deoxynucleotidyl transferase (TDT), which has upregulated expression in leukemia. ${ }^{\mathbf{9 8 , 1 0 0}}$ Arzumanov et al. screened dibromo species 56 against TDT but it was found to have lower affinity for TDT than the corresponding $\mathrm{P}-\mathrm{CF}_{2}-\mathrm{P}$ or $\mathrm{P}-\mathrm{O}-\mathrm{P}$ triphosphonate analog. ${ }^{\mathbf{9 8}}$

Carbocyclic dinucleoside polyphosphonates have shown activity against HIV reverse transcriptase-catalyzed DNA synthesis and hence demonstrate antiviral activity. ${ }^{97,99}$ Polyphosphonate $\mathbf{5 8}$ displayed weaker anti-HIV activity than the equivalent $\mathrm{CF}_{2}$ and $\mathrm{P}-\mathrm{O}-\mathrm{P}$ tetraphosphonate analogs. ${ }^{\mathbf{9 9}}$

It is important to note here that synthetic access to biologically interesting cyclic and acyclic $\alpha$-fluorophosphonate and $\alpha, \alpha$-difluorophosphonate nucleoside(-tide) analogs has been well studied and reviewed (e.g. 59, ${ }^{101} 60,{ }^{102} 61,{ }^{103} 62,{ }^{104}$ and $63,{ }^{105}$ Fig. 11). ${ }^{12}$ Analog 63 was tested as an inhibitor of purine nucleoside phosphorylase (PNP) which catalyzes the phosphorolysis of (deoxy)guanosine and (deoxy)inosine into guanidine and hypoxanthine. This class of inhibitors for PNP are of interest as potential immunosuppressive agents. ${ }^{12}$ The corresponding fully-saturated phosphonate of compound 63 was found to inhibit human erythrocyte PNP with a $K_{\mathrm{I}}$ of 174 $\mathrm{nM}$, while 63 had substantially increased activity. ${ }^{\mathbf{1 0 5}}$ These examples demonstrate the potential of $\alpha$-halogenated phosphonates as immunosuppressive agents, and the corresponding $\alpha$-bromo phosphonate compounds remain to be explored.

More recently it has been demonstrated that $\beta, \gamma$-methylenedGTP analogs can act as substrate mimics of dNTPs for DNA polymerase $\beta .^{106-109}$ Monobromo dGTP analog 66 was synthesized in one step by coupling $N, N^{\prime}$-dicyclohexylcarbodiimide (DCC)-activated dGMP with bisphosphonic acid (65) in 40\% yield (Scheme 17). This synthetic strategy mirrors that of the nucleosides presented above (Scheme 16). The dibromo dGMP analog has also been reported, which was accessed via phosphonic acid 54 in $40 \%$ yield (not shown). ${ }^{\mathbf{1 0 7}}$ To demonstrate the ability of $\beta, \gamma$-methylene-dGTP analogs to function as substrate mimics of DNA polymerase $\beta$, the authors obtained crystal structures of numerous halogenated $\beta, \gamma$-methylene-dGTP-DNA polymerase $\beta$ ternary complexes, including analog 66. ${ }^{109}$ They used this data to study the fidelity of DNA polymerase $\beta$ by<smiles>Nc1ncnc2c1ncn2C1O[C@H](CCC(F)(F)P(=O)(O)O)[C@@H](O)[C@H](O)[C@H]1O</smiles><smiles>NC1NC=Nc2c1ncn2C1OC(CCC(F)(F)P(=O)(O)OP(=O)(O)OP(=O)(O)O)C(O)C1[Hg]</smiles><smiles>Nc1ccn(C2OC(CO)C(CC(F)(F)P(=O)(O)O)C(O)C2O)c(=O)n1</smiles>

Fig. 11 Examples of $\alpha$-fluorinated phosphonate-based nucleosides(tides). 


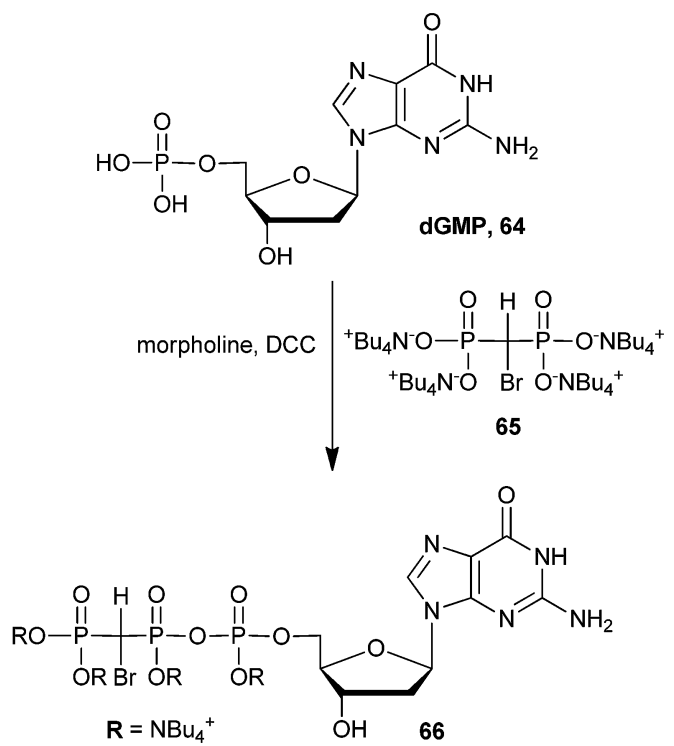

Scheme 17 Synthesis bromo-GTP analog 66 as a substrate for DNA polymerase $\beta .{ }^{107}$

looking at specific alterations in the active site due to binding of foreign nucleoside analogs. ${ }^{107,109}$ Recently, these authors expanded the library of $\beta, \gamma$-methylene-dNTP to include halogenated thymidine and cytidine analogs. They showed that binding of analog 66 and its dibrominated counterpart, as well as other halogenated $\beta, \gamma$-methylene dNTPs have tremendous effects on the transition state energies of DNA polymerase $\beta$ mediated catalysis. ${ }^{110}$ These results certainly show promise for a broadened utility of $\beta, \gamma$-bromomethylene dNTP analogs to function as substrate mimics for other polymerases and other enzyme systems.

\section{Conclusions and outlook}

There are a range of available methods to synthesize $\alpha$-bromophosphonates, and these allow versatile access to this functional group from alkyl, $\alpha$-hydroxy, or benzyl substituted phosphonate starting materials. The reports summarized here provide a survey of the known biological activities observed for $\alpha$-bromophosphonates and $\alpha, \alpha$-dibromophosphonates. This functional group has become an important bioisostere of the phosphate moiety, which can be used in the development of inhibitors and probes of phosphate-recognizing proteins. The ability of $\alpha$-bromophosphonates to act as specific covalent labels in PTP systems has enormous potential in the identification of new enzymes, and in the development of new specific inhibitors. The scope of the inhibitor activity of $\alpha$-bromophosphonates has recently been broadened to include GPCRs, ion channels, and glucose-6-phosphatase. The application of these compounds in mechanistic studies of enzymes, e.g. as dNTP mimics with polymerases, remains an area primed for expansion. The $\alpha$-brominated phosphonates are an important functional group in the toolbox of medicinal chemists and chemical biologists.

\section{Acknowledgements}

CWC would like to acknowledge support from the Natural Sciences and Engineering Research Council of Canada. AMD would like to thank the University of Alberta for a Queen Elizabeth II Graduate Scholarship.

\section{Notes and references}

1 D. M. Virshup and S. Shenolikar, Mol. Cell, 2009, 33, 537545.

2 P. G. Besant and P. V. Attwood, Biochem. Soc. Trans., 2012, 40, 290-293.

3 R. C. Nordlie, J. D. Foster and A. J. Lange, Annu. Rev. Nutr., 1999, 19, 379-406.

4 T. Maehama, F. Okahara and Y. Kanaho, Biochem. Soc. Trans., 2004, 32, 343-347.

5 H. L. Zhang, X. Y. Xu, J. Gajewiak, R. Tsukahara, Y. Fujiwara, J. X. Liu, J. I. Fells, D. Perygin, A. L. Parrill, G. Tigyi and G. D. Prestwich, Cancer Res., 2009, 69, 5441-5449.

6 G. Chan, D. Kalaitzidis and B. G. Neel, Cancer Metastasis Rev., 2008, 27, 179-192.

7 J. Y. Kim-Muller and D. Accili, Science, 2011, 331, 15291531.

8 L. Martin, X. Latypova and F. Terro, Neurochem. Int., 2011, 58, 458-471.

9 R. Engel, Chem. Rev., 1977, 77, 349-367.

10 P. C. Crofts and G. M. Kosolapoff, J. Am. Chem. Soc., 1953, 75, 3379-3383.

11 D. B. Berkowitz, M. Bose, T. J. Pfannenstiel and T. Doukov, J. Org. Chem., 2000, 65, 4498-4508.

12 V. D. Romanenko and V. P. Kukhar, Chem. Rev., 2006, 106, 3868-3935.

13 G. M. Blackburn, Chem. Ind., 1981, 134-138.

14 M. Ruiz, V. Ojea, J. M. Quintela and J. J. Guillin, Chem. Commun., 2002, 1600-1601.

15 M. B. Gazizov, R. A. Khairullin, A. I. Alekhina, I. A. Litvinov, D. B. Krivolapov, S. K. Latypov, A. A. Balandina, R. Z. Musin and O. G. Sinyashin, Mendeleev Commun., 2008, 18, 262264.

16 C. Schnaars and T. Hansen, Org. Lett., 2012, 14, 2794-2797.

17 A. P. Bento and F. M. Bickelhaupt, J. Org. Chem., 2008, 73, 7290-7299.

18 C. J. M. Stirling, Acc. Chem. Res., 1979, 12, 198-203.

19 J. B. Conant and B. B. Coyne, J. Am. Chem. Soc., 1922, 44, 2530-2536.

20 P. C. Crofts and G. M. Kosolapoff, J. Am. Chem. Soc., 1953, 75, 5738-5740.

21 T. Sagawa, S. Hirano, H. Takahasi, K. Hosoda, K. Togashi, M. Takeuchi, Y. Iwane and Y. Murakami, Japan Pat., JP 48001133 B, 1973.

22 F. G. Bordwell, Acc. Chem. Res., 1988, 21, 456-463.

23 T. Cantat, L. Ricard, P. Le Floch and N. Mézailles, Organometallics, 2006, 25, 4965-4976.

24 D. J. Collins, P. F. Drygala and J. M. Swan, Aust. J. Chem., 1984, 37, 1009-1021. 
25 H. Gross and S. Ozegowski, Phosphorus, Sulfur Silicon Relat. Elem., 1990, 47, 1-5.

26 V. V. Andriyashin, Y. V. Bakhtiyarova, R. A. Cherkasov, V. I. Galkin and I. V. Galkina, Zh. Org. Khim., 2012, 48, 1603-1604.

27 S. K. Chakraborty and R. Engel, Synth. Commun., 1991, 21, 1039-1046.

28 T. Pieper and B. K. Keppler, Phosphorus, Sulfur Silicon Relat. Elem., 2000, 165, 77-82.

29 F. Eymery, B. Iorga and P. Savignac, Tetrahedron, 1999, 55, 13109-13150.

30 A. N. Pudovik and I. V. Konovalova, Synthesis, 1979, 81-96.

31 T. Gajda, Phosphorus, Sulfur Silicon Relat. Elem., 1990, 53, 327-331.

32 S. Kumaraswamy, R. S. Selvi and K. C. K. Swamy, Synthesis, 1997, 207-212.

33 H. Gross, B. Costisella, S. Ozegowski, I. Keitelé and K. Forner, Phosphorus, Sulfur Silicon Relat. Elem., 1993, 84, 121-128.

34 D. Green, S. Elgendy, G. Patel, J. A. Baban, E. Skordalakes, W. Husman, V. V. Kakkar and J. Deadman, Tetrahedron, 1996, 52, 10215-10224.

35 H. Firouzabadi, N. Iranpoor and S. Sobhani, Synthesis, 2004, 290-294.

36 N. Iranpoor, H. Firouzabadi and M. Gholinejad, Can. J. Chem., 2006, 84, 1006-1012.

37 P. Balczewski, A. Szadowiak and T. Bialas, Heteroat. Chem., 2006, 17, 22-35.

38 W. P. Taylor, Z. Y. Zhang and T. S. Widlanski, Bioorg. Med. Chem., 1996, 4, 1515-1520.

39 S. Kumar, B. Zhou, F. B. Liang, W. Q. Wang, Z. H. Huang and Z. Y. Zhang, Proc. Natl. Acad. Sci. U. S. A., 2004, 101, 7943-7948.

40 N. S. Tulsi, A. M. Downey and C. W. Cairo, Bioorg. Med. Chem., 2010, 18, 8679-8686.

41 R. Gupte, R. Patil, J. X. Liu, Y. H. Wang, S. C. Lee, Y. Fujiwara, J. Fells, A. L. Bolen, K. Emmons-Thompson, C. R. Yates, A. Siddam, N. Panupinthu, T. C. T. Pham, D. L. Baker, A. L. Parrill, G. B. Mills, G. Tigyi and D. D. Miller, ChemMedChem, 2011, 6, 922-935.

42 G. W. Jiang, D. Madan and G. D. Prestwich, Bioorg. Med. Chem. Lett., 2011, 21, 5098-5101.

43 All chemically synthesized phosphonic acids are presented in the text as salts as they were originally isolated, or as a doubly protonated species if a counterion was not specified.

44 A. Saghatelian and B. F. Cravatt, Nat. Chem. Biol., 2005, 1, 130-142.

45 A. M. Sadaghiani, S. H. L. Verhelst and M. Bogyo, Curr. Opin. Chem. Biol., 2007, 11, 20-28.

46 B. Boivin, S. Zhang, J. L. Arbiser, Z. Y. Zhang and N. K. Tonks, Proc. Natl. Acad. Sci. U. S. A., 2008, 105, 9959-9964.

47 S. Kumar, B. Zhou, F. Liang, H. Yang, W. Q. Wang and Z. Y. Zhang, J. Proteome Res., 2006, 5, 1898-1905.

48 M. Umezu-Goto, Y. Kishi, A. Taira, K. Hama, N. Dohmae, K. Takio, T. Yamori, G. B. Mills, K. Inoue, J. Aoki and H. Arai, J. Cell Biol., 2002, 158, 227-233.
49 G. B. Mills and W. H. Moolenaar, Nat. Rev. Cancer, 2003, 3, 582-591.

50 G. W. Jiang, Y. Xu, Y. Fujiwara, T. Tsukahara, R. Tsukahara, J. Gajewiak, G. Tigyi and G. D. Prestwich, ChemMedChem, 2007, 2, 679-690.

$51 K_{\mathrm{I}}$ is the affinity of the compound for the enzyme and $K_{\mathrm{I}}^{\prime}$ is the affinity for the compound for the enzyme-substrate complex.

52 M. P. Teulade and P. Savignac, J. Organomet. Chem., 1988, 338, 295-303.

53 B. Iorga, F. Eymery and P. Savignac, Synthesis, 2000, 576580.

54 A. K. Bhattacharya and G. Thyagarajan, Chem. Rev., 1981, 81, 415-430.

55 N. A. Strotman, S. Sommer and G. C. Fu, Angew. Chem., Int. Ed., 2007, 46, 3556-3558.

56 S. F. Wnuk, L. A. Bergolla and P. I. Garcia, J. Org. Chem., 2002, 67, 3065-3071.

57 J.-P. Fu, Y.-H. He, J. Zhong, Y. Yang, X. Deng and Z. Guan, J. Fluorine Chem., 2011, 132, 636-640.

58 X. Y. Xu, G. H. Yang, H. L. Zhang and G. D. Prestwich, Prostaglandins Other Lipid Mediators, 2009, 89, 140-146.

59 X. Y. Xu and G. D. Prestwich, Cancer, 2010, 116, 1739-1750.

60 A. Nieto-Posadas, G. Picazo-Juárez, I. Llorente, A. JaraOseguera, S. Morales-Lázaro, D. Escalante-Alcalde, L. D. Islas and T. Rosenbaum, Nat. Chem. Biol., 2012, 8, 78-85.

61 B. Smith-Griffin and A. Burger, J. Am. Chem. Soc., 1956, 78, 2336-2338.

62 H. P. Albrecht, G. H. Jones and J. G. Moffatt, J. Am. Chem. Soc., 1970, 92, 5511-5513.

63 A. Vasella, G. Baudin and L. Panza, Heteroat. Chem., 1991, 2, 151-161.

64 J. Kovensky, M. McNeil and P. Sinay, J. Org. Chem., 1999, 64, 6202-6205.

65 D. B. Berkowitz, M. Eggen, Q. Shen and D. G. Sloss, J. Org. Chem., 1993, 58, 6174-6176.

66 D. B. Berkowitz and D. G. Sloss, J. Org. Chem., 1995, 60, 7047-7050.

67 D. B. Berkowitz, D. Bhuniya and G. Peris, Tetrahedron Lett., 1999, 40, 1869-1872.

68 A. M. Downey and C. W. Cairo, Carbohydr. Res., 2013, 381, 123-132.

69 L. K. Charkoudian, B. P. Farrell and C. Khosla, MedChemComm, 2012, 3, 926-931.

70 A. Ghosh, J. J. Shieh, C. J. Pan, M. S. Sun and J. Y. Chou, J. Biol. Chem., 2002, 277, 32837-32842.

71 V. Devreux, J. Wiesner, H. Jomaa, J. Van der Eycken and S. Van Calenbergh, Bioorg. Med. Chem. Lett., 2007, 17, 4920-4923.

72 A. M. Polozov and S. E. Cremer, J. Organomet. Chem., 2002, 646, 153-160.

73 J. Zeidler, J. Schwender, C. Müller, J. Wiesner, C. Weidemeyer, E. Beck and H. Jomaa, Z. Naturforsch., C: J. Biosci., 1998, 53, 980-986.

74 T. Kuzuyama, T. Shimizu, S. Takahashi and H. Seto, Tetrahedron Lett., 1998, 39, 7913-7916. 
75 M. S. Marma, Z. D. Xia, C. Stewart, F. Coxon, J. E. Dunford, R. Baron, B. A. Kashemirovli, F. H. Ebetino, J. T. Triffitt, R. G. G. Russell and C. E. McKenna, J. Med. Chem., 2007, 50, 5967-5975.

76 F. H. Ebetino, A.-M. L. Hogan, S. Sun, M. K. Tsoumpra, X. Duan, J. T. Triffitt, A. A. Kwaasi, J. E. Dunford, B. L. Barnett, U. Oppermann, M. W. Lundy, A. Boyde, B. A. Kashemirov, C. E. McKenna and R. G. G. Russell, Bone, 2011, 49, 20-33.

77 C. E. Mckenna and L. A. Khawli, J. Org. Chem., 1986, 51, 5467-5471.

78 A. Nakata, K. Kobayashi and H. Kogen, Chem. Pharm. Bull., 2013, 61, 108-110.

79 S. Zhao, Y.-H. He, D. Wu and Z. Guan, J. Fluorine Chem., 2010, 131, 597-605.

80 B. M. Baron, R. J. Cregge, R. A. Farr, D. Friedrich, R. S. Gross, B. L. Harrison, D. A. Janowick, D. Matthews, T. C. McCloskey, S. Meikrantz, P. L. Nyce, R. Vaz and W. A. Metz, J. Med. Chem., 2005, 48, 995-1018.

81 T. Olpp and R. Brückner, Synthesis, 2004, 2135-2152.

82 K. Tago and H. Kogen, Tetrahedron, 2000, 56, 8825-8831.

83 K. Tago and H. Kogen, Org. Lett., 2000, 2, 1975-1978.

84 C. D. Vanderwal, D. A. Vosburg, S. Weiler and E. J. Sorensen, J. Am. Chem. Soc., 2003, 125, 5393-5407.

85 C. D. Vanderwal, D. A. Vosburg and E. J. Sorensen, Org. Lett., 2001, 3, 4307-4310.

86 F.-L. Qing and X. Zhang, Tetrahedron Lett., 2001, 42, 59295931.

87 J. Vepsäläinen, H. Nupponen, E. Pohjala, M. Ahlgren and P. Vainiotalo, J. Chem. Soc., Perkin Trans. 2, 1992, 835-842.

88 D. W. Hutchinson and G. Semple, J. Organomet. Chem., 1985, 291, 145-151.

89 O. T. Quimby, J. D. Curry, D. A. Nicholson, J. B. Prentice and C. H. Roy, J. Organomet. Chem., 1968, 13, 199-207.

90 C. Lai, C. Xi and Y. Feng, Phosphorus, Sulfur Silicon Relat. Elem., 2004, 179, 449-455.

91 T. Ageno, T. Okauchi, T. Minami and M. Ishida, Org. Biomol. Chem., 2005, 3, 924-931.

92 B. Iorga and P. Savignac, J. Organomet. Chem., 2001, 624, 203-207.

93 V. P. Gubskaya, F. G. Sibgatullina, V. V. Yanilkin, V. I. Morozov, A. V. Toropchina, V. V. Zverev, N. M. Azancheev and I. A. Nuretdinov, Russ. Chem. Bull., 2005, 54, 1424-1429.

94 P. Balczewski and M. Mikolajczyk, Org. Lett., 2000, 2, 11531155.
95 P. Balczewski, Tetrahedron, 1997, 53, 2199-2212.

96 K. M. Błażewska, F. Ni, R. Haiges, B. A. Kashemirov, F. P. Coxon, C. A. Stewart, R. Baron, M. J. Rogers, M. C. Seabra, F. H. Ebetino and C. E. Mckenna, Eur. J. Med. Chem., 2011, 46, 4820-4826.

97 E. A. Shirokova, A. L. Khandazhinskaya, Y. S. Skoblov, L. Y. Goryunova, R. S. Beabealashvilli and A. A. Krayevsky, Nucleosides Nucleotides, 2001, 20, 1033-1036.

98 A. A. Arzumanov, L. S. Victorova and M. V. Jasko, Nucleosides Nucleotides, 2000, 19, 1787-1793.

99 A. L. Khandazhinskaya, E. A. Shirokova, Y. S. Skoblov, L. S. Victorova, L. Y. Goryunova, R. S. Beabealashvilli, T. R. Pronyaeva, N. V. Fedyuk, V. V. Zolin, A. G. Pokrovsky and M. K. Kukhanova, J. Med. Chem., 2002, 45, 1284-1291.

100 R. P. McCaffrey, T. A. Harrison, R. Parkman and D. Baltimore, N. Engl. J. Med., 1975, 292, 775-780.

101 J. Matulic-Adamic and N. Usman, Tetrahedron Lett., 1994, 35, 3227-3230.

102 S. F. Wnuk and M. J. Robbins, J. Am. Chem. Soc., 1996, 118, 2519-2520.

103 J. Matulic-Adamic, P. Haeberli and N. Usman, J. Org. Chem., 1995, 60, 2563-2569.

104 C. Lopin, A. Gautier, G. Gouhier and S. R. Piettre, J. Am. Chem. Soc., 2002, 124, 14668-14675.

105 C. E. Nakamura, S.-H. Chu, J. D. Stoeckler and R. E. Parks, Nucleosides Nucleotides, 1989, 8, 1039-1040.

106 C. A. Sucato, T. G. Upton, B. A. Kashemirov, P. Batra, V. Martínek, Y. Xiang, W. A. Beard, L. C. Pedersen, S. H. Wilson, C. E. Mckenna, J. Florián, A. Warshel and M. F. Goodman, Biochemistry, 2007, 46, 461-471.

107 C. A. Sucato, T. G. Upton, B. A. Kashemirov, J. Osuna, K. Oertell, W. A. Beard, S. H. Wilson, J. Florián, A. Warshel, C. E. Mckenna and M. F. Goodman, Biochemistry, 2008, 47, 870-879.

108 C. E. Mckenna, B. A. Kashemirov, T. G. Upton, P. Batra, M. F. Goodman, L. C. Pedersen, W. A. Beard and S. H. Wilson, J. Am. Chem. Soc., 2007, 129, 15412-15413.

109 V. K. Batra, L. C. Pedersen, W. A. Beard, S. H. Wilson, B. A. Kashemirov, T. G. Upton, M. F. Goodman and C. E. Mckenna, J. Am. Chem. Soc., 2010, 132, 7617-7625.

110 K. Oertell, B. T. Chamberlain, Y. Wu, E. Ferri, B. A. Kashemirov, W. A. Beard, S. H. Wilson, C. E. Mckenna and M. F. Goodman, Biochemistry, 2014, 53, 1842-1848. 